\title{
Spanish Legislation on Access to Records: the Case of the University of Navarra
}

\author{
YolandA CAGIGAS OCEJO, DR.
}

Director of the General Archive of the University of Navarra

e-mail:ycagigas@unav.es

\section{INES IRURITA HERNÁNDEZ}

Assistant Director of the General Archive of the University of Navarra

e-mail: irurita@unav.es

\section{Spanish Legislation on Access to Records: the Case of the University of Navarra}

\section{ABSTRACT}

This article analyses current Spanish legislation on access to public and private archives. It details the general legal regulations on access to records and the specific regulations on the right to honour, personal and family privacy, and personal image, as well as the regulations on intellectual property and the protection of personal data (which are also compared to the corresponding European regulations). The article also examines the regulations governing a specific period in Spanish history: namely, that of the Civil War and subsequent Franco dictatorship. Finally, the authors present the case study of a private archive and discuss the regulations governing access to the archive of the University of Navarra.

Key words: Legislation; Spain; access; archives; historical memory; protection of personal data; intellectual property; right to honour; private archives; university archives

Legislazione spagnola in materia di accesso ai record: il caso dell'Università di Navarra

\section{SINTESI}

Questo articolo analizza l'attuale legislazione spagnola sull'accesso agli archivi pubblici e privati. In dettaglio, le regolazioni legali generali sull'accesso ai documenti e le norme specifiche sul diritto al rispetto, alla privacy personale e familiare e dell'immagine personale, nonché le norme sulla proprietà intellettuale e la protezione dei dati personali (anche comparati alla corrispondente normativa europea). L'articolo esamina anche i regolamenti che disciplinano un periodo specifico della storia spagnola: quello cioè della guerra civile e della successiva dittatura franchista. Infine, gli autori presentano l'esempio di un archivio privato e discutono i regolamenti che disciplinano l'accesso all'archivio dell'Università di Navarra.

Parole chiave: Spagna, accesso, archivi, memoria storica, protezione dei dati personali, proprietà intellettuale, diritto al rispetto, archivi privati, archivi universitari

\section{Španska zakonodaja in dostop do arhivskega gradiva: primer Univerze v Navarri}

\section{IZVLE $\check{C} E K$}

Prispevek analizira trenutno špnakso zakonodajo o dostopu do javnih in privatnih arhivov. V njem so podrobno navedeni splošno pravni predpisi o dostopu do gradiva in posebni predpisi o pravici do časti, osebni in družinski zasebnosti, osebni podobi ter tudi predpisi o intelektualni lastnini in varstvu osebnih podatkov (ki so primerjani z ustreznimi evropskimi predpisi). Clanek obravnava tudi predpise, ki urejajo določeno obdobje v španski zgodovini: in sicer obdobje španske državljanske vojne in kasnejše diktature. Na koncu je predstavljena študija primera zasebnega arhiva in razprava o predpisih, ki urejajo dostop do arhiva Univerze v Navarri.

Ključne besede: zakonodaja; Španija; dostop; arhivi; zgodovinski spomin; varstvo osebnih podatkov; intelektualna lastnina; pravica do časti; zasebni arhivi; univerzitetni arhivi 
Yolanda CAGIGAS OCEJO - Ines IRURITA HERNÁNDEZ: Spanish Legislation on Access to Records: The Case of the University of Navarra, 71-81

\section{Introduction}

\subsection{The Concept of the Private Archive}

Article 59.1 of Law 16 of 25 June 1985 on Historical Spanish Heritage defines archives as "organic sets of records that are brought together by public or private legal personalities in the course of their activities for the purposes of research, culture, information and administrative management". The same article completes this definition by adding the following: "likewise, 'archives' shall also be understood to mean the cultural institutions where these organic sets of records are brought together, stored, organized and communicated for the aforementioned purposes".

As such, this law "provides for two realities in relation to the term 'archive' and makes the classical distinction between the container and the contents. Needless to say, the same distinction applies to private archives. Thus, we can focus our attention on the contents and refer to the set of records produced by a private legal personality; or we can focus on the container and refer to a private institution. Ultimately, the term 'private archive' refers to two separate realities: the set of records generated by a private productor, and a private institution that safeguards, preserves and diffuses a set or sets of records" (Cagigas 2015, p. 227).

When making a distinction between public and private archives, Antonia Heredia considered public archives to be "those whose ownership and management pertains to a public service or establishment, and whose records originate from or are the result of the exercise of a public function". She considered private archives to be "those that, on the contrary, originate from individuals or private legal personalities (individuals, families, associations, political parties, foundations, companies, churches, etc.)" (Heredia 2007, p. 58).

For its part, the Multilingual Archival Terminology database agrees with Heredia, inasmuch as it defines private archives as "archives and records originating from non-governmental organizations", although it also adds the concept of "personal papers", which it defines as "Documents created, acquired, or received by an individual in the course of his or her affairs and preserved in their original order"

As we stated in the 2015 publication cited above, although a distinction may be made between "public" and "private" in terms of the productor of the records, and in terms of the institution that houses the documents, no such distinction should be made in terms of archive users. Any archive, whether public or private, should make its records available to anyone who has the right to access them. This is not only a professional responsibility, but also a firm commitment that has been incorporated into the universal declaration made by the International Council on Archives (ICA), approved unanimously by UNESCO in 2011 and accepted by a multitude of archives and archivists:

"We undertake to ensure that archives are made accessible to everyone, while respecting the pertinent laws and the regulations on the rights of individuals, creators, owners and users."

\subsection{Spanish Legislation on Access}

- Spanish legislation on access to the information contained in records consists of the following laws:

- Organic Law 1 of 5 May 1982 on the Protection of Citizens' Rights to Honour, Personal and Family Privacy, and Personal Image.

- Law 16 of 25 June 1985 on Historical Spanish Heritage.

- Royal Legislative Decree 1 of 12 April 1996 approving the consolidated text of the Law on Intellectual Property and regulating, clarifying and harmonizing the current legal provisions in this area.

- Organic Law 15 of 13 December 1999 on the Protection of Personal Data.

- Royal Decree 1708 of 18 November 2011 creating the Spanish Archive System and regulating the Archive System of the General State Administration and its public bodies and their means of access.

- Law 52 of 26 December 2007 recognizing and extending rights and establishing measures for those who suffered from persecution or violence during the Spanish Civil War and subsequent dictatorship. 
Yolanda CAGIGAS OCEJO - Ines IRURITA HERNÁNDEZ: Spanish Legislation on Access to Records: The Case of the University of Navarra, 71-81

- Law 19 of 9 December 2013 on Transparency, Access to Public Information and Good Governance.

Although a bill for a new Organic Law on the Protection of Personal Data is currently making its way through the Spanish parliament, the present article is concerned only with legislation currently in force. To the aforementioned legislation, we must also add any corresponding regional laws. Naturally, we shall also take into account the new EU regulation that entered into force on 25 May 2018: Regulation (EU) 2016/679 of the European Parliament and of the Council of 27 April 2016 on the protection of natural persons with regard to the processing of personal data and on the free movement of such data, and repealing Directive 95/46/EC (General Data Protection Regulation).

\subsection{The retention and disposition schedule at Spanish Universities}

The Congress of Spanish University Archivists (CAU) is made up of professional archivists from public and private universities throughout Spain. Their aim is to collaborate on projects, activities and objectives designed to improve the management of documentary heritage at universities.

There are many different working groups within the CAU that aim to analyse specific topical matters that are of particular relevance to university archivists. The first of these groups was created in 1994 and is responsible for identifying and preparing the retention and disposition schedule of the records. The group's website contains proposals for identifying and assessing over 100 series. These proposals provide a good example of the application of Spanish legislation on access to archives.

\subsection{The General Archive of the University of Navarra}

The University of Navarra is a private Spanish university. According to the QS2019 international ranking, it is one of the world's top 250 universities $^{1}$. Its general archive holds the records produced by the university itself and a further 300 archives it has acquired through donations.

The donated archives relate to figures from Spanish public life, such as politicians, ministers, directors-general, business people from different industries, university professors, scientists, writers, architects, journalists, lawyers, ambassadors and diplomats, bishops, members of national and international associations, intellectuals, military figures, provincial governors, and publishers. The university also holds archives related to noble Spanish families.

Both the university's own archives and those that have been donated contain very recent records that could potentially affect the honour, privacy and image of those they concern, and could also have an impact on the protection of personal data and intellectual property.

The General Archive of the University of Navarra (AGUN) endeavours to systematize all of its processes and procedures, including the accession of archives and records, as well as record management, organization, classification and diffusion. This systematization makes the task of archiving simpler and easier, particularly in terms of access to records.

Specifically, the AGUN has developed rules that seek to guarantee the rights of researchers to access records while ensuring compliance with the current access-related legislation. It has also developed a system for the accession of donated archives.

In Spain, the experience of the AGUN has been documented and published in Spanish (Cagigas et al., 2016 and Irurita, 2012). However, the current article is aimed at an international audience and offers a complete and concise synthesis of Spanish legislation on access to archives. It also demonstrates how the AGUN has specifically tried to meet each of the challenges posed by the different pieces of legislation.

\section{The right to access records and reproductions}

Spanish legislation governing this area comprises, for the most part, Law 16 of 25 June 1985 on Historical Spanish Heritage and Royal Decree 1708/2011 creating the Spanish Archive System and regulating the Archive System of the General State Administration and its public bodies and their means of access.

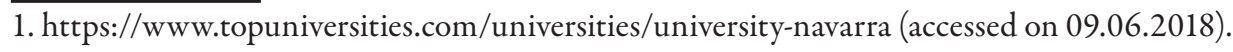


Yolanda CAGIGAS OCEJO - Ines IRURITA HERNÁNDEZ: Spanish Legislation on Access to Records: The Case of the University of Navarra, 71-81

Both pieces of legislation guarantee "access to public archives for all Spanish citizens" (Law $16 / 1985$, article 62), notwithstanding the limitations that are provided for therein:

"Every citizen has the right to access the records held at the archives that fall within the scope of this law, under the terms and conditions stipulated in this chapter and notwithstanding the exclusions and limitations provided for in the Constitution and other legislation. [...]" (Royal Decree 1708/2011, article 23.1).

In this respect, it is worth remembering the statement made above: namely, that "any archive, whether public or private, should make its records available to anyone who has the right to access them. This is not only a professional responsibility, but also a firm commitment".

In addition to other limitations, which we shall examine later, Royal Decree 1708/2011 stipulates that "access shall be restricted to records that are classified in accordance with the regulations on official secrets; records containing information whose disclosure may constitute a threat to national security or defence, hinder the investigation of offences or reduce the effective legal protection afforded to citizens and institutions; records that have been declared 'reserved' by law; and records containing personal data as referred to in article 28 " (article 26.1).

We should also point out that the aforementioned Royal Decree represents a significant qualitative leap forward over Law 16/1985, as it underlines archivists' responsibility to place themselves at the service of users: "The archivist shall offer the necessary assistance to facilitate the exercise of the right to access" (article 23.3). It goes on to say that: "to facilitate identification of the records requested, the archivist shall make available to the public finding aid and a description of the records, with the exception of those that cannot be listed in accordance with the limitations established by law" (article 24.4), later adding that: "Wherever possible, the archivist must make available to the public a list of records and sets of records to which access is restricted, with the exception of those whose existence must not be made public due to the interests they protect" (article 26.2).

Although the scope of this legislation extends only to public archives, in the words of Irurita, "once the AGUN has received and classified an archive, it produces an access report detailing any potential restrictions on access to particular archives or records, which are then excluded from public access. However, these sets or records are still described in finding aid and the reason for their exclusion is stated" (2012, p. 228).

In our 2016 article we addressed the provision of services to researchers, given that "if we had to describe the essence of the day-to-day activities of the staff working at the AGUN, like many other archives, it would consist of two key aspects: the desire to ensure continuous improvement in our work, and an explicitly service-oriented approach that (among other things) manifests itself in providing each user with diligent, personalized service" (Cagigas et al., 2016, p. 1223).

With regard to records held at an archive, Royal Decree 1708/2011 stipulates that "granting a request to access or view a record also grants the right to obtain a reproduction of the records requested, except under the following circumstances: a) when the records cannot be freely accessed; [...] c) when copying them would infringe intellectual property rights" (article 31.1 ).

For their part, the rules governing access to the AGUN state that:

"Researchers may ask for a reproduction of those records they consider to be of interest [...]. As a general rule, reproductions may not be made of records whose content infringes third-party rights protected by law. Upon receipt of a request from a researcher that specifies his/her reasons, archivists may consider making partial reproductions" (paragraphs 2 and 3).

Three issues related to archival access are examined below that must be given a significant amount of consideration in accordance with Spanish law.

\subsection{The Right to Honour, Personal and Family Privacy, and Personal Image}

The preface to Organic Law 1/1982 on the Protection of Citizens' Rights to Honour, Personal and Family Privacy, and Personal Image states that, "in accordance with article 18.1 of the Spanish Constitution, the right to honour, personal and family privacy, and personal image are considered fundamental, 
and they are described as such in the Constitution; article 24 of which stipulates that respect for these rights places a limit on the exercise of freedom of expression, which the Constitution also recognizes, classifies and protects as fundamental".

In this respect, Law 16/1985 on Historical Spanish Heritage stipulates that "records containing personal data of a political, legal, clinical or any other nature that may affect an individual's safety, honour, personal and family privacy, or personal image may not be subject to public access without the express consent of the data subject or until 25 years after his/her death (where the date is known), or 50 years after the date of the records" (article 53.c).

However, it would appear that a period of 25 years following the death of the data subject offers insufficient guarantee of the aforementioned rights, as Law 1/1982 stipulates that the heirs may act to defend the data subject's honour up to 80 years after his/her death. "Taking civil action to protect the honour, privacy or image of a deceased individual [...] provid-
ed no more than 80 years have passed since the individual's death" (articles 4-6).

The same law describes the following as "unlawful infringement": "the disclosure of information related to the private life of individuals or families that may affect their reputation and good name, or the disclosure or publication of the contents of letters, memoirs or other personal writings of a private nature" (article 7). It also adds that, "in general, activities authorized or consented to by the competent authorities in accordance with the corresponding legislation, or when there is a relevant cultural, historical or scientific interest, shall not be considered 'unlawful infringements"' (article 8.1).

In this respect, the rules governing access to the AGUN stipulate the following:

\begin{abstract}
"Four. Researchers undertake to refrain from using the information they access for purposes that are not permitted by law. In particular, they undertake to respect the right to honour and privacy on the part of individuals whose data may be contained in the records they access, with this access being granted solely and exclusively for the purposes declared in the request.

Six. If a researcher's failure to meet these obligations results in the filing of a claim by third parties against the University of Navarra, the researcher undertakes to personally assume liability and exempt the University of Navarra from same.

Seven. Researchers shall inform the AGUN staff of the existence of any records to which they may have access and which may contain any information whose disclosure could lead to an infringement of the right to honour and personal and family privacy, along with the existence of any letters, memoirs or other writings that may be considered personal andlor of a private nature. Researchers shall not communicate this information to third parties or disclose it via any medium, whether directly or indirectly, without the prior and express consent of the affected parties. This consent must be requested through the AGUN."
\end{abstract}

Additionally, to ensure greater awareness of the legislation that protects these rights, the AGUN provides researchers with a summary of the key aspects of the laws in question.

\title{
2.2 Intellectual Property
}

Spanish legislation governing intellectual property consists of Royal Decree 1 of 12 April 1996 approving the consolidated text of the Law on Intellectual Property.

All archives hold records that are subject to intellectual property protection. Those cited in the aforementioned legislation include the following: "a) [...] letters, writings, speeches, addresses, talks, forensic reports, keynotes and any other records of a similar nature; [...] f) Blueprints, plans, models and designs for architectural and engineering works; [...] h) Photographic works and those created using procedures analogous to photography" (article 10.1).

With regard to the right of exploitation, we should note that "the author has the exclusive right to exploit his/her work in any way, and particularly the right to copy, distribute, publish and transform it. These actions may not be performed without the author's authorization" (article 17). We should also note that these rights "shall persist for the duration of the author's life and for 70 years after his/her death or declaration of death" (article 26). 
Yolanda CAGIGAS OCEJO - Ines IRURITA HERNÁNDEZ: Spanish Legislation on Access to Records: The Case of the University of Navarra, 71-81

However, the legislation does permit copying for educational or research purposes, under the following terms:

\begin{abstract}
"Copyright holders cannot oppose the copying of their works when said copies are not made for monetary gain, are made by museums, libraries (including music, film and news libraries) public archives or archives that form part of a cultural or scientific institution, and are only made for research or conservation purposes" (article 37.1).
\end{abstract}

Thus, when requesting copies, researchers at the AGUN must sign a document specifying how they will use the copies and whether they are for research, educational or commercial purposes.

However, if an archive wishes to free itself entirely from any difficulties in this area, the best solution is to acquire, where possible, the right to exploit the materials in question. The legislation states that "the right to exploitation may be transferred on an inter vivos basis" (article 43.1).

The legislation also states that "all transfers must be formalized in writing. If the grantee fails to meet this requirement, having been duly asked to do so, the grantor may choose to terminate the agreement" (article 45).

The document formalizing the transfer must specify the form, duration and scope, given that "failure to specify the duration shall limit the transfer to a period of five years, and failure to specify the scope shall limit it to the territorial limits of the country in which the transfer takes place. Failure to specify the forms in which the works may be exploited shall limit transfer to those forms that can be deduced from the agreement and are considered essential to fulfil the purpose of the transfer" (article 43.2).

Ideally, this transfer will be made on an exclusive basis. "Exclusive transfers must expressly state their exclusivity and shall grant the grantee, within the scope of the transfer, the power to exploit the works on an exclusive basis, with the grantor also excluded from doing so. Unless agreed otherwise, the grantee shall also have the power to grant non-exclusive authorizations to third parties. The grantee shall also have the right, independently of the rights of the grantor, to take action in response to any infringements of the powers that have been granted to him/her" (article 48).

To facilitate normal archival activities, such as online communication and publication, organizing exhibitions and/or loaning records to other institutions for exhibition purposes, all donated archives at the AGUN are subject to a written agreement that covers all of the considerations detailed above, as well as the following:

"Five. Within the context of cultural and research purposes, and consequently the disclosure and diffusion that form an essential part of scientific and technical research, this donation expressly includes the transfer, on an exclusive and indefinite basis (or for the maximum period permitted by law), of all rights of use and exploitation for all of the works that comprise the donated archive, including usage in part and encompassing all forms of copying, distribution, publication and transformation via any format and medium, including audiovisual and computer media, multimedia, telecommunications media, etc."

Although the rights of exploitation may be transferred, certain other copyrights are (logically) inalienable and cannot be renounced, such as "the right to demand recognition of one's authorship of the work" (article 14.3).

Although it is common practice in all archives, and therefore not necessary to set down in writing, the aforementioned donation agreement also stipulates the following:

"Six. The donation of this archive represents the transfer of its ownership to the University of Navarra, which shall henceforth become the owner and assume the following responsibilities: [...] 5. Cite the name of this archive using the following format: General Archive of the University of Navarral (Name and Surname(s)) fond".

\title{
2.3 Protection of Personal Data
}

In Spain, the current legislation that governs this area chiefly comprises Organic Law 15 of 13 December 1999 on the Protection of Personal Data. As mentioned above, at present the bill for a new data protection law is making its way through the Spanish Parliament; however, in this article we are con- 
cerned only with the legislation currently in force. The matter is also dealt with in Royal Decree 1708 of 18 November 2011 creating the Spanish Archive System and regulating the Archive System of the General State Administration and its public bodies and their means of access, specifically in article 28, "Access Requests for Restricted Documents Containing Personal Data”. These laws are complemented by Regulation (EU) 2016/679 of the European Parliament and of the Council of 27 April 2016 on the protection of natural persons with regard to the processing of personal data and on the free movement of such data, and repealing Directive 95/46/EC (General Data Protection Regulation).

The aim of Law 15/1999 is "to guarantee and protect the public freedoms and fundamental rights of natural persons with regard to the processing of their personal data, especially with regard to their honour and personal and family privacy" (article 1).

First, we need to understand the precise definition that the legislation gives to key concepts:
“a) Personal data: any information pertaining to identified or identifiable individuals.
[...]
f) Dissociation procedure: any processing procedures involving personal data by means of which
the information obtained cannot be associated with an identified or identifiable individual.
[...]
i) Transfer or diffusion of data: any disclosure of data to a party other than the data subject"
(article 3).

This law also stipulates that "the personal data being processed may be disclosed only with third parties for purposes directly related to the legitimate functions of the grantor and grantee, and subject to the prior consent of the data subject" (article 11.1). This condition is also stipulated in Royal Decree $1708 / 2011$, which adds that "records containing personal data that may affect the safety or privacy of individuals may be accessed only 25 years after the death of the data subject" (article 28.2).

Both laws allow for the possibility of access via dissociation: Law 15/1999 in article 11 and Royal Decree 1708/2011 as follows: "access shall be granted to records containing personal data, without the need for the prior consent of the owners of said data, when dissociation procedures have been performed to prevent the identification of the data subject" (article 28.4).

The same law also allows for access to records of historical interest, provided they contain data only of a nominative nature:
"Access to records containing data of a nominative or merely identifying nature, which do not affect the safety or privacy of the data subject, shall be permitted when the owner of said data is deceased or when the requesting party proves that helshe has a legitimate interest in accessing said records. To this end, a 'legitimate interest' shall be considered to apply to those requesting access to exercise their rights, and to researchers who can prove they are accessing the records for historical, scientific or statistical purposes" (article 28.3).

With regard to the aforementioned European legislation, which does not conflict with Spanish legislation in any way, the key provision regarding access to archives is article 89, "Safeguards and derogations relating to processing for archiving purposes in the public interest, scientific or historical research purposes or statistical purposes", paragraph 1 of which states the following:

\begin{abstract}
"Processing for archiving purposes in the public interest, scientific or historical research purposes or statistical purposes, shall be subject to appropriate safeguards, in accordance with this Regulation, for the rights and freedoms of the data subject. Those safeguards shall ensure that technical and organizational measures are in place, in particular in order to ensure respect for the principle of data minimization. Those measures may include pseudonymization, provided that those purposes can be fulfilled in that manner. Where those purposes can be fulfilled by further processing which does not permit or no longer permits the identification of data subjects, those purposes shall be fulfilled in that manner."
\end{abstract}

Law 19 of 9 December 2013 on Transparency, Access to Public Information and Good Governance is concerned with both the right to access information and natural persons' right to protection. This law guarantees the right of all citizens to access public information, and as this right may enter into conflict with the right to the protection of natural persons, the law stipulates that although access shall be given to information that directly affects public activity, if said information contains personal data sub- 
Yolanda CAGIGAS OCEJO - Ines IRURITA HERNÁNDEZ: Spanish Legislation on Access to Records: The Case of the University of Navarra, 71-81

ject to special protection, it will first be necessary to obtain the consent of the data subject. As stipulated in article 12, "all citizens have the right to access public information under the terms provided for in article 105.b) of the Spanish Constitution, which this law implements. Likewise, within the scope of their respective competences, the corresponding regional regulations shall also apply". Article 15 adds:

\begin{abstract}
"1. If the information requested contains data subject to the special protection described in section 2 of article 7 of Organic Law 15 of 13 December 1999 on the Protection of Personal Data, access may be granted only when the data subject has given his/her express written consent [...]. If the information requested contains data that is subject to the special protection described in section 3 of article 7 of Organic Law 15 of 13 December 1999, or data concerning the commission of criminal or administrative offences that have not resulted in the public sentencing of the perpetrator, access may be granted only when the data subject has given his/her express consent or when access is permitted by law [...].

3. If the information requested does not contain data that is subject to special protection, the body to which the request is made shall decide whether or not to grant access [...].

When deciding whether or not to grant access, the body in question shall place particular importance on the following criteria: [...] b) Justification of the request on the basis of exercising a right, or on the basis that the requesting party is a researcher and requires access for historical, scientific or statistical purposes".
\end{abstract}

\title{
2.4 Legislation for the Period 1936-1975
}

Special mention should be made of the Law of Historical Memory (Law 52 of 26 December 2007), which aims to "recognize and extend rights to those who suffered from persecution or violence for political or ideological reasons or because of their religious beliefs during the Civil War and subsequent dictatorship; to promote the repair of the moral damage caused and the recovery of personal and family memories; and to adopt complementary measures designed to remove sources of division between citizens, with the overarching aim of promoting cohesion and solidarity based on constitutional freedoms, values and principles among the different generations of Spanish citizens" (article 1.1). "Using the tool of public policy, in the form of this law, the aim is to promote democratic principles and values by facilitating knowledge of the events and circumstances of the Civil War and subsequent dictatorship, and to thereby ensure the preservation of records related to this historical period in public archives" (article 1.2).

This law led to the creation of the Documentary Centre for Historical Memory and the General Archive for the Civil War (article 20), whose contents are defined as follows: "all of the original records or certified copies of records that refer to the Civil War of 1936-1939 and the subsequent period of political repression and are located in state museums, libraries or archives. These institutions shall retain a digital copy of said records" (article 20.2.a).

Article 49 of Law 16 of 25 June 1985 on Historical Spanish Heritage defines the records that form part of Spain's documentary heritage. These include records "more than 40 years old that were generated, held or collated by political or religious bodies or associations; trade unions; private bodies or foundations; or cultural or educational associations over the course of their activities" (article 49.3). In other words, from 2015 onwards private archives containing records from 1975 (or earlier) have been obliged to grant access to those records. As such, the new legislation stipulating that "records that are held in public and private archives and are related to the Civil War and subsequent dictatorship form part of Spain's documentary heritage" (article 21.2) would not appear to significantly modify the current situation with regard to access.

Article 22 deals with the right to access records held in public and private archives, and stipulates the following:

"1. For the purposes provided for herein, the right to access the records held in public archives is guaranteed, as is the right to request and obtain copies of said records.

2. The provisions of the foregoing paragraph shall be applied, under their own terms, to private archives that are fully or partly supported by public funds". 


\section{APPENDIX}

\section{Navarra \\ Rules Governing Access to Personal Archives within the General Archive of the University of}

One. When accessing the archives, researchers are under the very strictest of obligations to keep the fonds whole. As such, they are strictly prohibited from removing, altering the order of, or destroying any of the records that form part of the fonds.

Two. Researchers may ask for copies of those records they consider to be of interest. Copies may be made only by the archive's staff. Under no circumstances may researchers make copies themselves (e.g. by photographing, scanning or digitizing the records). Researchers shall bear the costs of making any copies they request.

Three. As a general rule, copies may not be made of records whose content infringes third-party rights protected by law. Upon receipt of a request from a researcher that specifies his/her reasons, archivists may consider making partial copies.

Four. Researchers undertake to refrain from using the information they access for purposes that are not permitted by law. In particular, they undertake to respect the right to honour and privacy on the part of individuals whose data may be contained in the records they access, with this access being granted solely and exclusively for the purposes declared in the request.

Five. Where applicable, researchers shall comply with the stipulations of Organic Law 15 of 13 December 1999 on the Protection of Personal Data.

Six. If a researcher's failure to meet these obligations results in the filing of a claim by third parties against the University of Navarra, the researcher undertakes to personally assume liability and exempt the University of Navarra from same.

Seven. Researchers shall inform the AGUN staff of the existence of any records to which they may have access and which may contain any information whose disclosure could lead to an infringement of the right to honour and personal and family privacy, along with the existence of any letters, memoirs or other writings that may be considered personal and/or of a private nature. Researchers shall not communicate this information to third parties or disclose it via any medium, whether directly or indirectly, without the prior and express consent of the affected parties. This consent must be requested through the AGUN. To aid your understanding of the regulations that protect these rights, we have provided you with a summary of the main points to take into consideration when conducting historical research.

Eight. Express authorization from the AGUN is required to publish or disclose copies of records in any format and/or medium.

\section{References}

Organic Law 1 of 5 May 1982 on the Protection of Citizens' Rights to Honour, Personal and Family Privacy, and Personal Image. Available at: https://www.boe.es/buscar/pdf/1982/BOE-A-1982-11196-consolidado.pdf (accessed on 09.06.2018).

Law 16 of 25 June 1985 on Historical Spanish Heritage. Available at: https://boe.es/buscar/pdf/1985/ BOE-A-1985-12534-consolidado.pdf (accessed on: 09.06.2018).

Royal Legislative Decree 1 of 12 April 1996 approving the consolidated text of the Law on Intellectual Property and regulating, clarifying and harmonizing the current legal provisions in this area. Available at: https://www.boe. es/buscar/pdf/1996/BOE-A-1996-8930-consolidado.pdf (accessed on 09.06.2018).

Organic Law 15 of 13 December 1999 on the Protection of Personal Data. Available at: https://www.boe.es/ buscar/pdf/1999/BOE-A-1999-23750-consolidado.pdf (accessed on 09.06.2018).

Royal Decree 1708 of 18 November 2011 creating the Spanish Archive System and regulating the Archive System of the General State Administration and its public bodies and their means of access. Available at: https://www. boe.es/buscar/pdf/2011/BOE-A-2011-18541-consolidado.pdf (accessed on 09.06.2018). 
Yolanda CAGIGAS OCEJO - Ines IRURITA HERNÁNDEZ: Spanish Legislation on Access to Records: The Case of the University of Navarra, 71-81

Bill for the Organic Law on the Protection of Personal Data. Available at: http://www.congreso.es/public_oficiales/L12/CONG/BOCG/A/BOCG-12-A-13-1.PDF (accessed on 09.06.2018).

Regulation (EU) 2016/679 of the European Parliament and of the Council of 27 April 2016 on the protection of natural persons with regard to the processing of personal data and on the free movement of such data, and repealing Directive 95/46/EC (General Data Protection Regulation). Available at: https://www.boe.es/doue/2016/119/ L00001-00088.pdf (accessed on 09.06.2018).

IRURITA HERNÁNDEZ, Inés (2012). Los archivos personales y familiares en el Archivo General de la Universidad de Navarra: el difícil equilibrio entre el libre acceso y la restricción de uso. Tábula, 15. pp. 223-232.

HEREDIA HERRERA, Antonia (2007). ¿Qué es un archivo? Trea, Gijón.

Multilingual Archival Terminology. Available at: http://www.ciscra.org/mat/ (accessed on 09.06.2018).

Universal Declaration on Archives, International Council on Archives (ICA). Available at: https://www.ica.org/ en/universal-declaration-archives (accessed on 09.06.2018).

CAGIGAS OCEJO, Yolanda et al. (2016). El Archivo General de la Universidad de Navarra, Principe de Viana $(P V), 266$, septiembre-diciembre, pp. 1193-1233. Available at: https://dialnet.unirioja.es/descarga/articulo/6030107.pdf (accessed on 09.06.2018).

CAGIGAS OCEJO, Yolanda (2015). Los archivos privados como fuente para la Historia de la Educación, en La Educación en España. Historia y archivos, Actas de las XI Jornadas de Castilla-La Mancha sobre investigación en archivos, Archivo Histórico Provincial de Guadalajara, pp. 227-247. Available at: http://www.s354988462.mialojamiento.es/archivo-guadalajara/actas-XI-jornadas/files/assets/basic-html/index.html\#1 (accessed on 09.06.2018).

Bill for the Organic Law on the Protection of Personal Data. Available at: http://www.congreso.es/public_oficiales/L12/CONG/BOCG/A/BOCG-12-A-13-1.PDF (accessed on 09.06.2018).

The Spanish Constitution. Available at: https://www.boe.es/buscar/doc.php?id=BOE-A-1978-31229 (accessed on 09.06.2018).

Grupo de Trabajo de Identificación, Valoración y Clasificación de series documentales de la CAU, Estudio de series documentales. Available at: http://cau.crue.org/documentos/grupos-de-trabajo/grupo-de-trabajo-de-identificacion-valoracion-y-clasificacion-de-series-documentales/estudio-de-series/ (accessed on 09.06.2018).

Law 52 of 26 December 2007 recognizing and extending rights and establishing measures for those who suffered from persecution or violence during the Spanish Civil War and subsequent dictatorship. https://www.boe.es/ buscar/pdf/2007/BOE-A-2007-22296-consolidado.pdf.

Law 19 of 9 December 2013 on Transparency, Access to Public Information and Good Governance. Available at: https://www.boe.es/boe/dias/2013/12/10/pdfs/BOE-A-2013-12887.pdf (accessed on 09.06.2018).

\section{SUMMARY}

From the entry into force of the Spanish Constitution in 1978 and up to the adoption of Regulation (EU) 2016/679 of the European Parliament and of the Council of 27 April 2016 on the protection of natural persons with regard to the processing of personal data and on the free movement of such data, a number of laws, decrees, regulations and other instruments were passed to govern access to the information contained in records. This article analyses current Spanish legislation governing the professional activities of archivists, who must have an understanding of and respect this legislation to be able to facilitate citizen access while protecting the rights of those very citizens as well as any others affected by the records or information being accessed. Spanish legislation establishes the right of citizens to access records held in archives, protects them against unlawful infringement and sets out the related obligations that must be met by archivists. Consequently, archivists must have an understanding of the legislation that protects the producers of the records held in the archives and the individuals referred to therein. To achieve this, archivists must first identify, describe, classify and assess the records; a process which necessarily involves studying the information they contain. In accordance with current legislation, as a general rule, free access is granted to records. Where records are reserved or access is restricted, the reasons for this shall be specified in accordance with the legal provisions in which said reservations or restrictions are stipulated. This information must also be given to archive users so they understand why they cannot access certain records. As an example of the application of the rules governing access to records, we have included the rules governing access to the General Archive of the University of Navarra. These rules aim to respect all current regulations while also enabling users and 
Yolanda CAGIGAS OCEJO - Ines IRURITA HERNÁNDEZ: Spanish Legislation on Access to Records: The Case of the University of Navarra, 71-81

researchers to access certain recently acquired fonds containing information that could potentially affect the honour, privacy and image of individuals. In many cases, this information is also subject to intellectual property law.

Typology: 1.01 Original scientific article

Submission date: 29.06 .2018

Acceptance date: 08.08 .2018 